\title{
EU Regional Policy and the Absorption Rate of European Structural and Investment Funds in Romania
}

\author{
Ramona Mariana CALINICA ${ }^{\star}$
}

\begin{tabular}{l}
\hline \multicolumn{1}{c}{ A R T I C L E I N F O } \\
\hline Article history: \\
Accepted August 2020 \\
Available online August 2020 \\
\hline JEL Classification \\
E52 \\
Keywords: \\
Absorption rate, Regional policy, \\
European funds \\
\hline
\end{tabular}

\begin{abstract}
A B S T R A C T
The importance of EU regional policy and especially the impact it has on Romania's economic development it is uncontested. In this paper the focus will be on analysis of the of the regional development policy of the European Union, identifying the main objectives and principles on which regional policy applies, determining the funds involved in financing programs and projects and identifying the results achieved in Romania, analyzing the level and evolution of their absorption rate.
\end{abstract}

(C) 2020 EAI. All rights reserved.

\section{Introduction}

In the conditions in which the European Union certainly reflects an advanced form of integration, that has created over the time, within it, a highly competitive area and considerably increasing the level of economic development of the acceding states, however between them are still exists disparities in development and productivity that shows a major weakness [3] and a vulnerability of this organization. In this regard, EU regional policy involves the exclusions of all disparities that exists in this moment between regions and supports their unequivocal development, and as much as possible is desired a solution to all regional problems. [1] The Romania's integration process was a major step and a significant opportunity in terms of application the regional development policy. Therefore, Romania should strive for rational use of resources allocated funds in order to implement appropriate policies for economic, social and territorial cohesion and to achieve the objectives set. The main challenge in Romania is the identification of financial resources to resolve economic, social difficulties, arising from differences between regions.

\section{Definition, objectives and principles of regional development policy}

Regional policy is a complex one with a significant impact on the development of various states, as it's a strategic investment policy that aims to stimulate economic growth of all EU regions and cities and improve the quality of citizens' life [7]. At the same time, cohesion policy focuses on supporting and developing regions that are poorer and less developed (Chart 1)

Figure 1. Objectives within the Cohesion Policy during 2014-2020 (\% of the allocated budget)

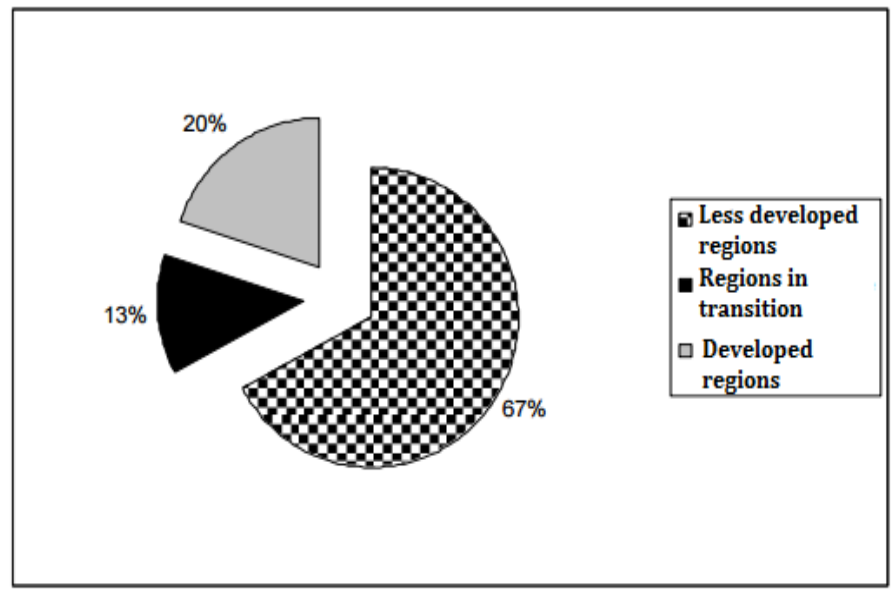

Source: http://oaji.net/articles/2016/3365-1467972013.pdf [2] 
The five EU objectives for 2020 are as follows [5]:

1. Employment:

* among the population aged 20 to 64 , the employment rate must be $75 \%$;

2. Reasearch and development:

* granting 3\% of the European Union's GDP in the direction of research and development; up to $20 \%$;

3. Decrease of greenhouse gas emissions by $20 \%$, growth the share of renewable energy sources by

Developing energy efficiency by $20 \%$;

4. Education:

* reducing the school abandonment below $10 \%$;

* increasing the share to over $40 \%$ of graduates with higher education among the population aged 30 34 ;

5. Combating poverty and social exclusion:

* decreas the number of affected people by both poverty and social exclusion (with 20 million) and improving the situation.

Nationwide, each Member State has adopted national targets in these areas.

Thematic objectives for the 2014-2020 financial framework is directed towards convergence, regional competitiveness and European territorial cooperation. These 11 goals are as follow [11]:

1. Reasearch, innovation and technological development;

2. Achieving access to and use of ICT (information and communication technology) and increasing its quality;

3. SMEs' competitiveness promotion;

4. Supporting the transition to a low carbon economy;

5. Risk management and prevention and increasing adaptation to climate change;

6. Resource use development and environmental protection;

7. Promoting transport network infrastructure and reducing bottlenecks;

8. Encourage quality employment and supporting labor mobility;

9. Combating poverty and any other form of discrimination, promoting social inclusion;

10. Education allocation resources, education and training, including vocational training;

11. Public authorities, public administrations and public services capacity building.

The following principles underlying the functioning of structural policy at Community level: the programming principle; the partnership principle; the principle of additionality; the concentration principle. This set of principles does not exclude national principles, but on the contrary, joins them, emphasizes and directs national policy towards preparing access to the financial instruments of regional policy.

The Programming principle assumes that individual projects are not funded but allows for the development of multi-annual development programs in line with EU objectives and priorities, to which is added a partnership decision-making process.

The Partnership principle refers to a set of rules and actions involving officials of the European Commission, national governments and regional authorities, together with local businesses, trade unions and social action groups need to work together in developing, implementing and monitoring programs financed by the EU funded cohesion programmes [4].

The Principle of additionality: it provides that expenses incurred by countries national or regional level can not be substituted in grant funding from international funds, but to complement these expenses [1].

The Concentration principle it targets three aspects, namely:

* resource concentration - the orientation of resources mainly towards poorly developed states and regions;

* concentration of effort directing to certain areas;

* concentrate of spending - establishing an annual financing on projects and programs to be spent within a maximum of two years from the allocation.

\section{Cohesion policy and the absorption level of ESIF in Romania}

In the next financial framework, 373 billion euros will be allocated, after the period 2014-2020 when were allocated 351.8 billion euros from the total EU budget, for cohesion policy, in order to meet the objectives or various needs existing at all EU regions level. 
Figure 2. The cohesion policy allocated budget

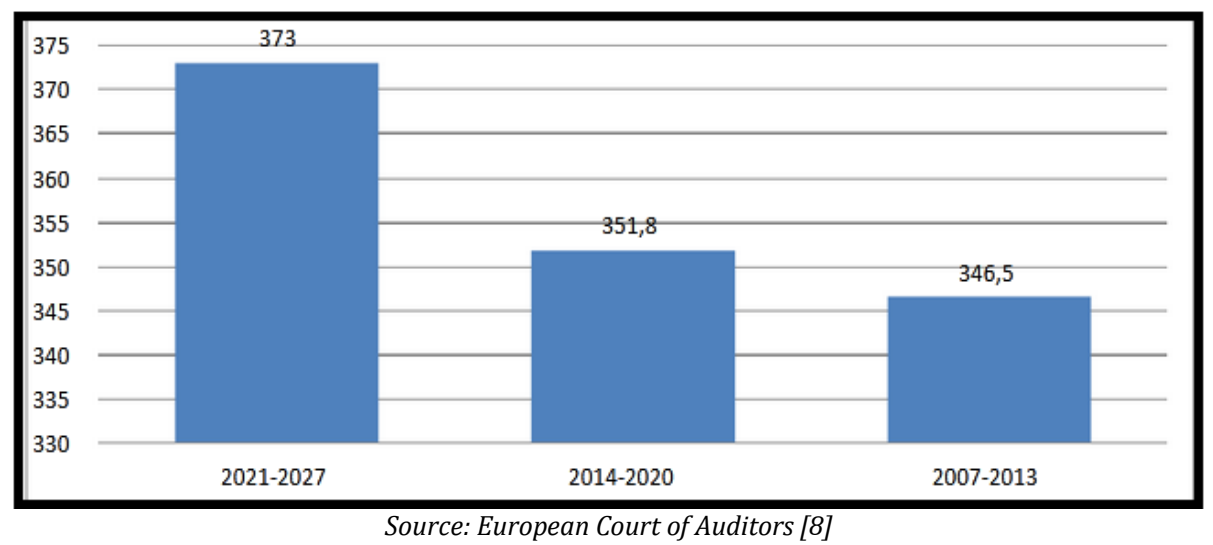

Between 2014-2020, Romania had the chance to invest in all 11 thematic objectives, using ESI funds and operational programs.

Figure 3. Structural and Investment Funds - Romania

\begin{tabular}{|l|l|l|l|}
\hline Fund & EU Amount & National Amount & Total Amount \\
\hline ESF & $4,622,917,320$ & $811,053,914$ & $5,433,971,234$ \\
\hline CF & $6,934,996,977$ & $1,223,822,998$ & $8,158,819,975$ \\
\hline EAFRD & $8,127,996,402$ & $1,516,964,563.90$ & $9,644,960,965.90$ \\
\hline YEI & $302,237,196$ & $26,667,988$ & $328,905,184$ \\
\hline ERDF & $10,726,080,699$ & $2,232,534,661$ & $12,958,615,360$ \\
\hline EMFF & $168,421,371$ & $55,116,541.01$ & $223,537,912.01$ \\
\hline \multicolumn{4}{|c|}{ Source: Comisia Europeană [6] } \\
\hline
\end{tabular}

In March 2019, Romania recorded an absorption rate of European funds 28\% below the EU average of 29\%. The amount received by Romania from the European Commission was EUR 8.5 billion of the total allocation of 31 billion euros. (figure 4). In the period that followed, the degree of absorption had an upward trend, so that on June 1, 2020 the absorption rate reached the level of $41 \%$, but is still below the EU average of $46 \%$. Regarding the amount received from the European Commission, it was 12.92 billion euros from 31 billion allocation for the programming period 2014-2020 [9].

Figure 4. Absorption rate in Romania, March 2019

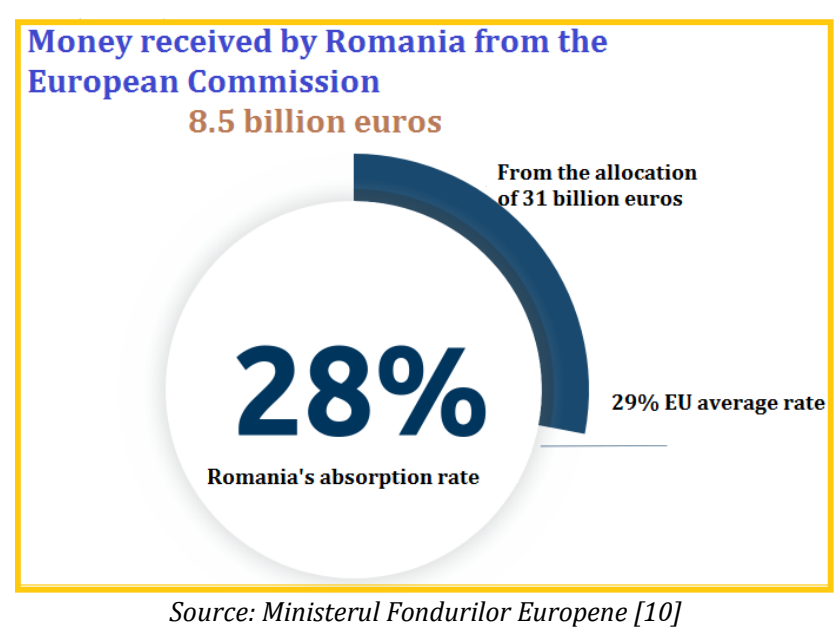

Table 1 gives an overview of the 2014-2020 financial allocations for each operational program. It can be observed that the largest amount is allocated through the Large Infrastructure Operational Programme, approximately 9.21 billion euros, followed by the Regional OP, approximately 6.86 billion euros and the OP Human Capital around 4.37 billion euros. Regarding the effective absorption rate, the highest percentage was registered at the level of the Technical Assistance Operational Programme, namely 58.25\%, followed by the 
Competitiveness Operational Programme 25.36\%, the OP Human Capital 25.33\%, and the lowest percentage was registered at the level of the Regional Operational Programme, namely 21,46\% (table 1).

Table 1. The absorption stage in Romania on June 1, 2020

\begin{tabular}{|c|c|c|c|c|c|}
\hline \multirow{3}{*}{$\begin{array}{l}\text { Programs } \\
2014-2020\end{array}$} & \multirow{2}{*}{$\begin{array}{c}\text { Allocation } \\
2014-2020 \\
\text { (EU) }\end{array}$} & \multicolumn{2}{|c|}{ EC repayment (effective absorption rate) } & \multicolumn{2}{|c|}{$\begin{array}{l}\text { Total amount received from the EC } \\
\text { (including pre-financing) }\end{array}$} \\
\hline & & Value & $\%$ & Value & $\%$ \\
\hline & 1 & 2 & $3=(2 / 1) * 100$ & 4 & $5=(4 / 1) * 100$ \\
\hline Regional OP & $6,860,000,000$ & $1,472,277,565$ & $21.46 \%$ & $2,280,176,890$ & $33.24 \%$ \\
\hline Large Infrastructure OP & $9,218,524,484$ & $2,238,283,506$ & $24.28 \%$ & $3,162,457,954$ & $34.31 \%$ \\
\hline Competitiveness OP & $1,329,787,234$ & $337,174,089$ & $25.36 \%$ & $468,306,763$ & $35.22 \%$ \\
\hline OP Human Capital & $4,371,963,027$ & $1,107,566,971$ & $25.33 \%$ & $1,515,165,792$ & $34.66 \%$ \\
\hline $\begin{array}{l}\text { OP Administrative } \\
\text { Capacity }\end{array}$ & $553,191,489$ & $121,942,548$ & $22.04 \%$ & $176,400,305$ & $31.89 \%$ \\
\hline Technical Assistance OP & $252,765,958$ & $147,243,511$ & $58.25 \%$ & $177,092,327$ & $70.06 \%$ \\
\hline SUBTOTAL & $22,586,232,192$ & $5,424,488,190$ & $24.02 \%$ & $7,779,600,031$ & $34.44 \%$ \\
\hline$N R D P$ & $8,127,996,402$ & $4,765,747,421$ & $58.63 \%$ & $5,090,867,277$ & $62.63 \%$ \\
\hline OPFMA & $168,421,371$ & $42,316,024$ & $25.13 \%$ & $57,949,739$ & $34.41 \%$ \\
\hline TOTAL ESIF & $30,882,649,965$ & $10,232,551,635$ & $33.13 \%$ & $12,928,417,046$ & $41.86 \%$ \\
\hline ADOP & $441,013,044$ & $120,427,017$ & $27.31 \%$ & $168,938,452$ & $38.31 \%$ \\
\hline EAGF 2015-2020 & $11,395,870,660$ & $8,663,941,361$ & $76.03 \%$ & $8,663,941,361$ & $76.03 \%$ \\
\hline
\end{tabular}

EC- European Commission

Source: Ministerul Fondurilor Europene[12]

OP- Operational Programme

ADOP- Assistance for Disadvantaged People Operational Programme

EAGF- European Agricultural Guarantee Fund

If we take into account all the amounts received from the European Commission, the total absorption rate from the ESI funds was $41.86 \%$, and regarding the breakdown by operational programs, it can be seen that the higher level was registered in the case of the Technical Assistance Operational Programme 70.06\%, followed by the Competitiveness Operational Programme 35.22\%, the OP Human Capital 34.66\% Large Infrastructure OP 34.31\%, the Regional OP 33.24\% and OP Administrative Capacity 31.89\% (table 1). Although the situation has improved, the absorption rate increasing, at some point being eliminated the risk of decommissioning, though Romania is still below the EU average in terms of absorption.

\section{Conclusions}

The funds allocated by the European Union, designed to help create prosperous economies and to the existing difficulties reduction, represent a great development opportunity for all EU member states and implicitly for Romania. To meet the objectives set, economic, social and territorial development is an important target for Romania, which for this purpose must make every effort to succeed in attracting a large volume of investments from EU funds.

It seeks an efficient allocation of program, a good distribution of financial resources and objectives in different fields, is important to develop each one, and finally performing assessment results and on establishing new development priorities. For the 2014-2020 financial framework, Romania, based on the Partnership Agreement signed with the European Commission, has invested from European Structural Funds in all 11 thematic objectives. Thus, these funds represent financial instruments designed to help the country achieve the objectives set and meet the requirements of the European Union.

Regarding the absorption rate, although it has registered an upward trend lately, Romania is still below the EU average in terms of absorption of European Structural and Investment Funds.

\section{References}

1. Bache, I. George, S. (2009), Politica în Uniunea Europeană., , Editura Epigraf, Chişinău, p. 493-502

2. Dragoi, A., Politica de coeziune- un pilon essential pentru atingerea obiectivelor Europa 2020, available at http://oaji.net/articles/2016/3365-1467972013.pdf

3. Ghica, L.A, Preda, C. (2007), Enciclopedia Uniunii Europene. Ediția a III-a., Editura Meronia, București, p. 5.

4. Molle, W. (2009), Economia integrării europene. Teorie, practică, politici., Editura Epigraf, București, pag. 321.

5. Comisia Europeană, (2015), Europa 2020. Obiectivele Europa 2020, http://ec.europa.eu/europe2020/europe-2020-in-anutshell/targets/index_ro.htm

6. Comisia Europeană Fonduri structurale și de investiții europene, available at https://cohesiondata.ec.europa.eu/dataset/ESIF-Budget-by-Fund-Romania/g2ey-wfzd 
7. Comisia Europeană, Politica regională, available at https://ec.europa.eu/regional_policy/ro/policy/what/investment-policy/

8. European Court of Auditors, Rapid case review Allocation of Cohesion policy funding to Member States for 2021-2027, available at https://www.eca.europa.eu/lists/ecadocuments/rcr_cohesion/rcr_cohesion_en.pdf

9. Ministerul Fondurilor Europene, Evolutia fondurilor europene in cifre, available at http://mfe.gov.ro/situatia-fondurilor-europene-1iunie/

10. Ministerul Fondurilor Europene, Evolutia fondurilor europene in România, available at http://mfe.gov.ro/evolutia-fonduriloreuropene-in-romania/

11. Ministerul Fondurilor Europene, Programe, (2014), Programe Operationale, avalilable at: $h t t p: / / w w w . f o n d u r i-u e . r o / p o$

12. Ministerul Fondurilor Europene, Stadiul absorbtiei - 1 iunie 2020, available at https://data.gov.ro/dataset/stadiul-absorbtieifondurilor-europene/resource/cce3af60-7f97-4601-b232-c3091783b7ac?inner_span=True 